Z. klin. Chem. u. klin. Biochem.

10. Jg. 1972 , S. $99-103$

\title{
Semiautomatic Method for the Separation and Determination of Total Triiodothyronine and Thyroxine in Serum
}

\author{
By K. Horn, T. Ruril and P. C. SCribA ${ }^{1}$ ) \\ II. Medizinische Klinik (Direktor: Prof. Dr. E. Bucbborn) der Universität Mïnchen
}

(Eingegangen am 9. August 1971)

\begin{abstract}
A semiautomatic procedure is presented for the scparate determination of total $T_{3}$ and $T_{4}$ in serum in approximately 10 hrs simultaneously in 25 samples. Removal of the thyroid hormones from the serum, separation of $T_{3}$ from $T_{4}$ and concentration of the peaks were achicved in a closed system, consisting of three consecutive columns. The automatic microchemical iodine determination of $T_{3}$ and $T_{4}$ respectively, had a sensivity of less than $0.5 \mathrm{ng}$. Recovery for $\mathrm{T}_{3}$ was $87 \%$ and for $\mathrm{T}_{4} 88 \%$. High accuracy and reproducibility could be shown with pooled control scrum. The overspill of $T_{4}$ into $T_{3}$ was less than $0.1 \%$ of total $T_{4}$.

The means of total scrum $T_{3}$ and $T_{4}$ were $1.46 \pm 0.20$ (S. D.) $\mu \mathrm{g} / \mathrm{l}$ and $76.5 \pm 10.7 \mu \mathrm{g} / 1$ respectively for euthyroid controls. In paticnts with nontoxic goiter the $T_{4}$ levels were significantly lower than in euthyroid controls, whereas the $T_{3}$ levels and the $T_{3}$ : $T_{4}$ ratio were significantly higher.
\end{abstract}

Es wird eine semiautomatische Methode für die simultane Analyse von 25 Proben beschrieben, welche dic getrennte Bestimmung des Gesamt-Trijodthyronins und -Thyroxins im Serum innerbalb von etwa 10 Stunden erlaubt. Die Abtrennung der Schilddrüsenhormone von den Scrumproteinen, dic Trennung von $T_{3}$ und $T_{4}$ und die Konzentricrung der jeweiligen Eluatc erfolgte in cincm geschlossenen System, bestchend aus drei aufeinanderfolgenden Säulen. Die automatische mikrochemische Jodbestimmung für $T_{3}$ bzw. $T_{4}$ hat cine Empfindlichkeit von weniger als $0,5 \mathrm{ng}$. Die Wiederfinderaten waten für $\mathrm{T}_{3}: 87 \%$ und für $\mathrm{T}_{4}: 88 \%$. Die Richtigkeit und Präzision der Methode waren zufriedenstellend. Weniger als $0,1 \%$ des gesamten $T_{4}$ gehen in dic $T_{3}$-Fraktion ein.

Bei cuthyreoten Kontrollpersonen fanden sich Serum- $T_{3}$-Spiegel von $1,46 \pm 0,20 \mu \mathrm{g} / \mathrm{l}(\overline{\mathrm{x}} \pm \mathrm{s})$ und Thyroxin-Spiegel von 76,5 $\pm 10,7 \mu \mathrm{g} / 1$. Bei Patienten mit blander Struma waren die Gesamt-Thyroxin-Spiegel signifikant im Vergleich zu Kontrollpersonen erniedrigt, während die $T_{3}$-Spiegel und der $T_{3}: T_{4}$-Quotient signifikant erhöht waren.

The clinical significance of the levels of total triiodothyronine ${ }^{2}$ ) in serum is of growing interest. Several techniques for the determination of triiodothyronine in serum have been developed. STERLING and WERnER have both employed paper chromatography (1-7), whereas recently radioimmunological methods have been developed $(8-10)$. All these techniques have been subject to substantial criticism (4-7).

The method developed in our laboratory during the past years consists basically of three steps: (1) Removal of thyroid hormones from serum proteins, (2) separation of $\mathrm{T}_{3}$ from $\mathrm{T}_{4}$ and (3) quantitation of $\mathrm{T}_{3}$ and $\mathrm{T}_{4}$ by microchemical iodine determination. Continuous chromatography in a closed system consisting of three consecutive columns diminished artefacts. Simultaneous chromatography of 25 samples was achieved using a 25-channel peristaltic pump in order to obtain partial automation and standardization of the procedure. Preliminary results of the study have been reported $(11,12)$.

\section{Materials and Methods}

Cation exchange resins: AG $50 \mathrm{~W}-\mathrm{X} \mathrm{4}$, minus 400 mesh, hydrogen form; Bio-Rex 70, 50-100 mesh, sodium form (Bio-Rad Laboratories, Richmond, Calif.). Dextran gels: Sephadex G-25, supcrfine; Sephadex LH-20 (Pharmacia, Uppsala).

1) Supported by the Deutsche Forschungsgemeinschaft (Sonderforschungsbereich 51).

2) Abbreviations: $T_{3}=$ trilodothyronine, $T_{4}=$ thyroxine, MIT $=$ monoiodotyrosine, DIT $=$ diiodotyrosine, $\mathrm{PBI}=$ protein bound iodine.
Radioactive compounds: Liothyronine-125 1 (3, 5, 3'-triiodo-t-thyronine), $20-50 \mathrm{mC} / \mathrm{mg}$; L-thyroxine- ${ }^{125} \mathrm{l}, 20-50 \mathrm{mC} / \mathrm{mg} ; 3,5-$ diido-L-tyrosine-125 $\mathrm{I}, 25-100 \mathrm{mC} / \mathrm{mg}$ and 3-iodo-L-tyrosine-125 $\mathrm{I}$, $0.1-2 \mathrm{mC} / \mathrm{mg}$, all in $50 \%(\mathrm{v} / \mathrm{v})$ aqueous propylene glycol solution (Radiochemical Centre, Amersham).

Stable compounds: 3,3',5-triiodo-L-thyronine, puriss.; L-thyroxine, purum; 3,5-diiodo-L-tyrosine, purum and 3-iodo-L-tyrosine, purum (Fluka AG, Buchs, Switzerland); 3, 5, 3', 5'-tetraiodothyroacetic acid (Serva, Heidelberg).

\section{Removal of ' $\mathrm{T}_{3}$ and $\mathrm{T}_{4}$ from serum proteins}

The cation exchange resin AG $50 \mathrm{~W}-\mathrm{X} 4$ ( $\mathrm{H}^{+}$-form) was washed three times with $0.1 \mathrm{~N} \mathrm{HCl}$. After discarding the last supernatant, an equal volume of $0.1 \mathrm{~N} \mathrm{HCl}$ was added to the washed resin. Two $\mathrm{ml}$ of this $1: 1(\mathrm{v} / \mathrm{v})$ continuously stirred suspension were pipetted into each of 25 glass microcolumns. (volume $5 \mathrm{ml}$ ) with the outlet closed (Fig. 1, a). Serum $(2.5 \mathrm{ml}$ ) or standard solution were added. The microcolumns werc then closed by glass stoppers. Removal of $T_{3}$ and $T_{4}$ from serum was obtained by mixing the content of each of the 25 microcolumns on a rotor for $30 \mathrm{~min}$ at room temperature. Each microcolumn was washed with $10 \mathrm{ml}$ 1N potassium chloride (Fig. $1, \mathrm{~b}$ ), to exchange all the $\mathrm{H}^{+}$-ions against $\mathrm{K}^{+}$-ions. The eluates containing proteins and iodide were discarded. The microcolumns with $T_{3}$ and $T_{4}$ bound to the resin were then linked to the second columns.

Separation of $\mathrm{T}_{3}$ and $\mathrm{T}_{4}$ on Sephadex G-25

Twentyfive glass columns $(\mathrm{h}=130 \mathrm{~mm}, \mathrm{~d}=11 \mathrm{~mm})$ mounted in a waterbath of $27^{\circ} \mathrm{C}$ werc filled with a suspension of $4 \mathrm{~g} \mathrm{Se}$ phadex G-25 superfine and washed with $0.05 \mathrm{M}$ potassium phosphate buffer ( $\mathrm{pH} 11.9$ ) at a constant rate of $0.42 \mathrm{ml}$ per min using a peristaltic pump (25-channcl micto-pump, Ismatec, Zürich). The supernatant buffer was removed from the Sephadex. The microcolumns of the first step were then put on top of these Sephadex columns (Fig. 1, c). $T_{3}$ and $T_{4}$ werc cluted together in a narrow peak from the resin with $0.05 \mathrm{M}$ potassium phosphate buffer $\mathrm{pH} 11.9$ (peristaltic pump) and simultancously layered onto the Scphadex 


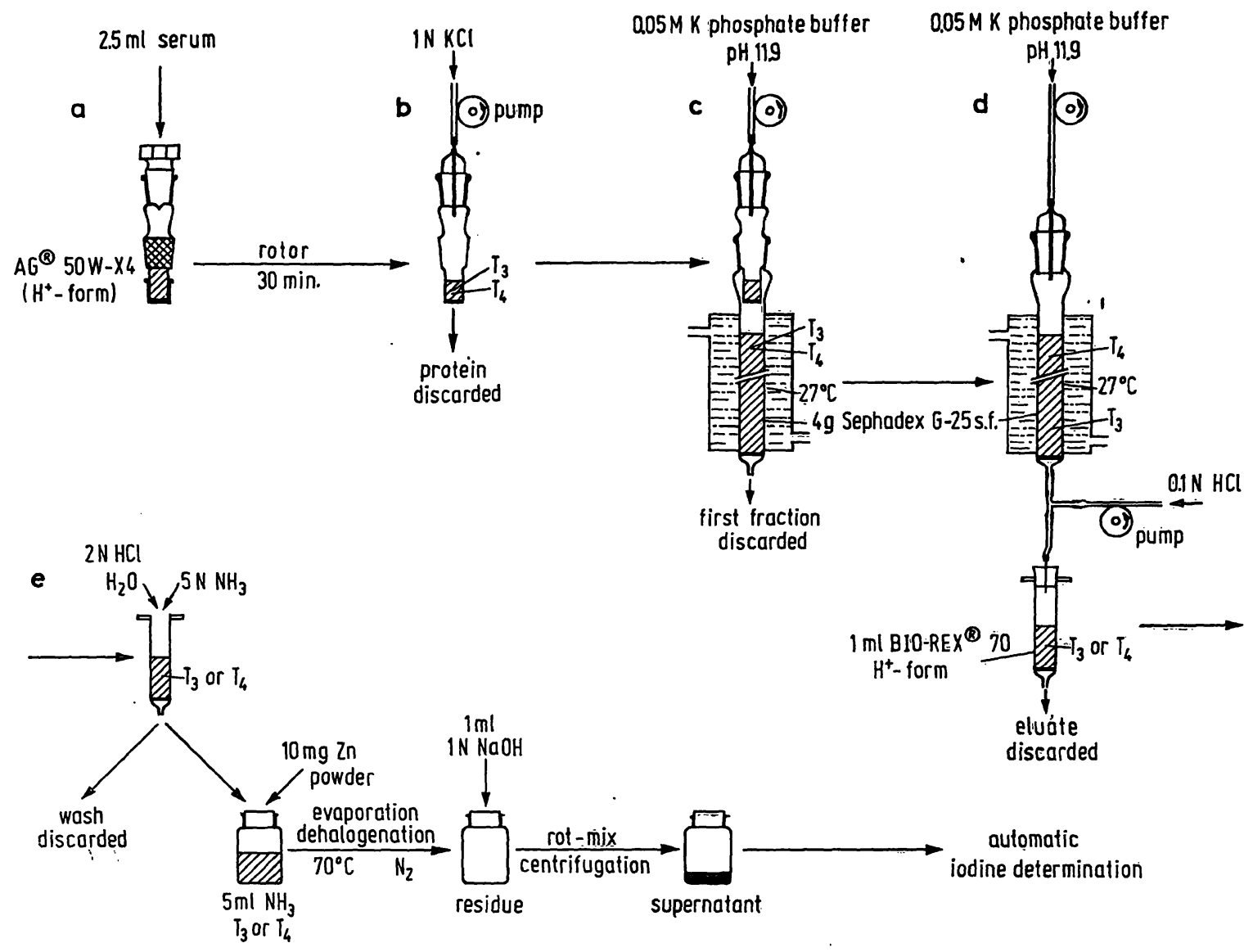

Fig. 1

Schematic presentation of the method. For explanation see text

columns. One milliliter fractions were collected and good separation could be achieved (Fig. 2). Therefore for routine purposes batch sampling of $T_{3}$ and $T_{4}$, combined with separate concentration of $T_{3}$ and $T_{4}$ on cation exchange resins, was performed (Fig. 1, d).

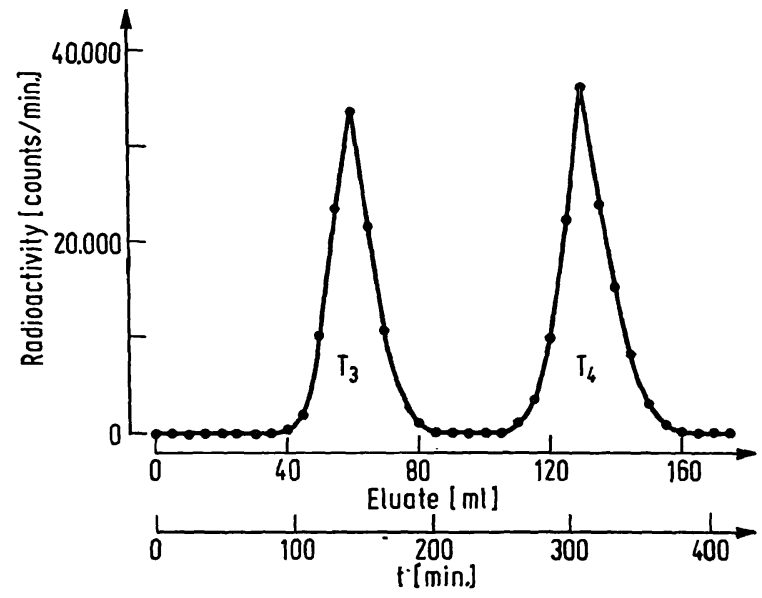

Fig. 2

Separation of $T_{3}$ from $T_{4}$ on Sephadex G-25 superfine

The figure shows the elution of radioactive standards in serum subjected to the first two steps of the method. The radioactivity of the fractions collected is given versus the volume and the time of elution respectively

Concentration of the $\mathrm{T}_{3}$ and $\mathrm{T}_{4}$ batches on cation exchange resin

The concentrating columns (polypropylene syringes, $2 \mathrm{ml}$ ) each contained $1 \mathrm{ml}$ Bio-Rex 70, $\mathrm{H}^{+}$-form. The latter was prepared from the sodium form by repeated washing with hydrochloric acid. .

The first $40 \mathrm{ml}$ from the Sephadex G-25 column were discarded

(Fig. 2). The eluate $\left(T_{3}\right.$ or $\left.T_{4}\right)$ was then continuously acidified with $0.1 \mathrm{~N} \mathrm{HCl}$ by means of a second 25-channel micro-pump (Ismatec, Zürich) at a rate of $0.23 \mathrm{ml}$ per min. The fractions containing $\mathrm{T}_{3}$ or $\mathrm{T}_{4}$ (Fig. 2) were subsequently layered onto Bio-Rex 70 columns for retention of $T_{3}$ and $T_{4}$ respectively (Fig. 1, d).

The Bio-Rex columns containing $T_{3}$ or $\mathrm{T}_{4}$ were first washed with $7.5 \mathrm{ml} 2 \mathrm{~N} \mathrm{HCl}$ and then with $15 \mathrm{ml}$ water (Fig. 1, e). $\mathrm{T}_{3}$ or $\mathrm{T}_{4}$ were then eluted with $5 \mathrm{ml} 5 \mathrm{~N} \mathrm{NH}_{3}$ into glass vials. After the addition of approximately $10 \mathrm{mg}$ of zinc powder activated by cuprous sulfate for reductive dehalogenation (13), the samples were evaporated at $70^{\circ} \mathrm{C}$ within $30 \mathrm{~min}$ under nitrogen (Fig. 1, e), the gas being recycled in a closed system. This step also proviided the necessary deiodination of the thyroid hormones (13). The evaporated residue was dissolved in $1 \mathrm{ml} 1 \mathrm{~N} \mathrm{NaOH}$, mixed for $20 \mathrm{~min}$ and centrifuged briefly.

Quantitation of $\mathrm{T}_{3}$ and $\mathrm{T}_{4}$

The automatic microchemical iodine determination in the solved residues was performed in a continuous flow system as published (13). The sensitivity of the microchemical analysis can be seen from the standard curve (Fig. 3). - The measured values were corrected against the yield of a control serum incubated with labeled $T_{3}$ and $T_{4}$ (Table 1 ). All data reported represent the mean of duplicate analyses.

Table 1

Quality control of the complete procedure

\begin{tabular}{|c|c|c|}
\hline Quality control from day to day: & $T_{s}$ & $\mathbf{T}_{4}$ \\
\hline $\begin{array}{l}\text { Recovery of added }{ }^{125} \text { I-labeled } \\
\text { hormone }\end{array}$ & $\begin{array}{l}86.7 \pm 4.9 \% \\
(N=15)\end{array}$ & $\begin{array}{c}88.4 \pm 4.1 \% \\
(N=15)\end{array}$ \\
\hline Reproducibility of control serum & $\begin{array}{c}1.45 \pm 0.14 \mu \mathrm{g} / \mathrm{l} \\
(\mathrm{N}=14)\end{array}$ & $\begin{array}{c}55.8 \pm 3.8 \mu \mathrm{g} / 1 \\
(\mathrm{~N}=16)\end{array}$ \\
\hline $\begin{array}{l}\text { Values of healthy controls: } \\
\text { No goiter, no medication, } \\
\text { normal weight }\end{array}$ & $\begin{array}{c}1.46 \pm 0.20 \mu \mathrm{g} / \mathrm{l} \\
(\mathrm{N}=23) \\
\text { Means }\end{array}$ & $\begin{aligned} & 76.5 \pm 10.7 \mu \mathrm{g} / \mathrm{l} \\
+\mathrm{SD} & (\mathrm{N}=23)\end{aligned}$ \\
\hline
\end{tabular}




\section{Diagnostica}

MERCK

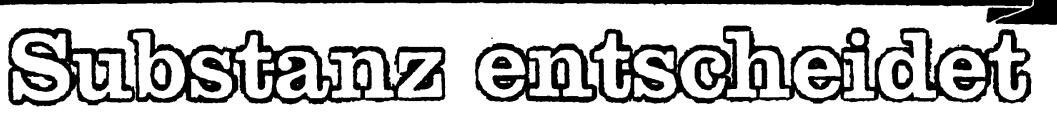

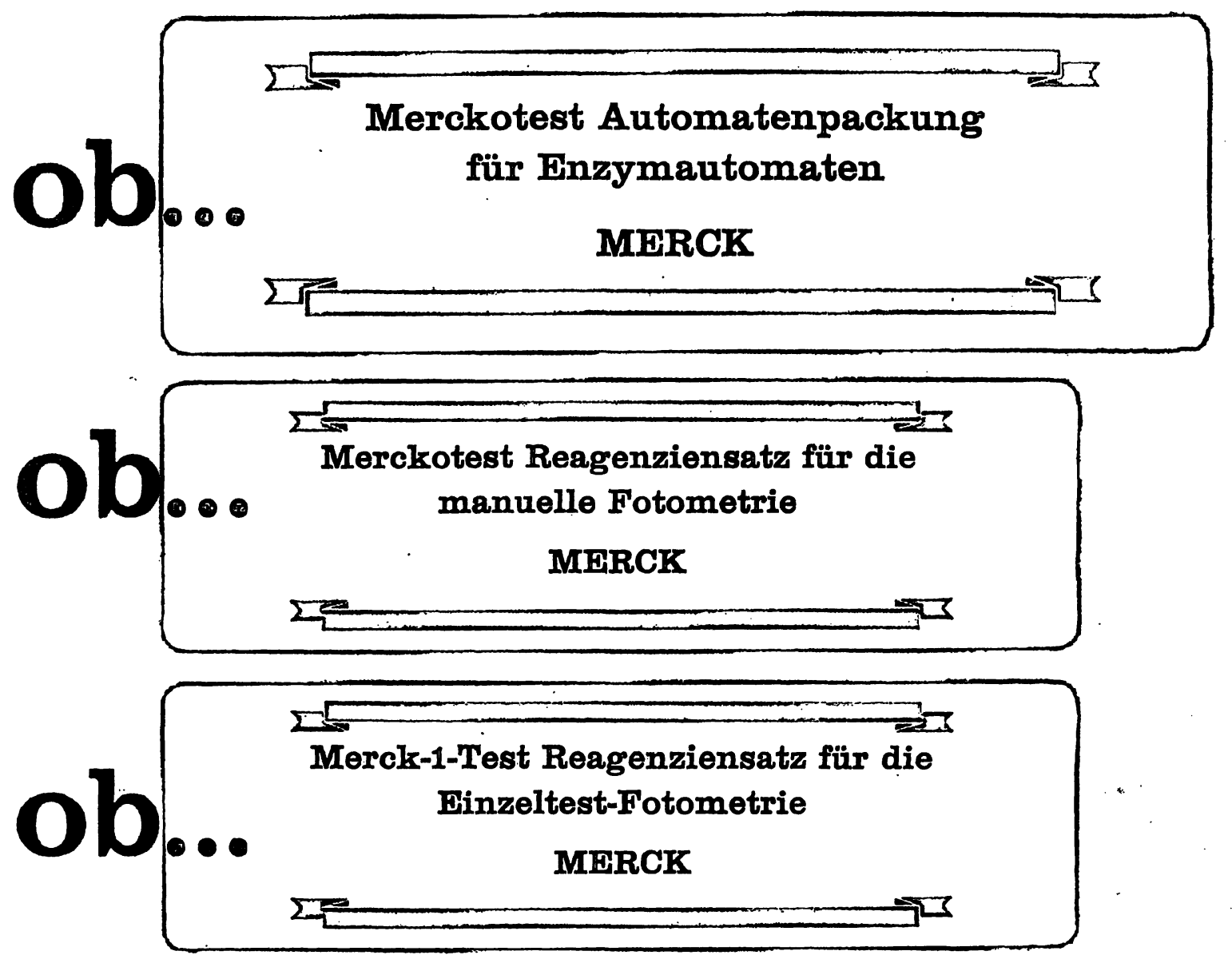

Merck hat alle Voraussetzungen geschaffen für die Vergleichbarkeit der Laborergebnisse in Klinik und Praxis durch standardisierte Enzymbestimmungen mit optimierten Tests :

Alkalische Phosphatase (AP)

Cholinesterase (CHE)

Glutamat-Oxalacetat-Transaminase (GOT)

Glutamat-Pyruvat-Transaminase (GPT)

a-Hydroxybutyrat-Dehydrogenase (HBDH)

Lactat-Dehydrogenase (LDH)

Leucin-Arylamidase (sog. LAP)

Spezialprospekte "Merckotest Automatenpackungen", "Merckotest" und „Merck-1-Test" senden wir Ihnen gern auf Anforderung zu.

E. Merck, Darmstadt 


\section{Niedermolekulare Substanzen schnell und wirksam trennen}

\section{mit der Hochspannungs-}

\section{Elektrophorese}

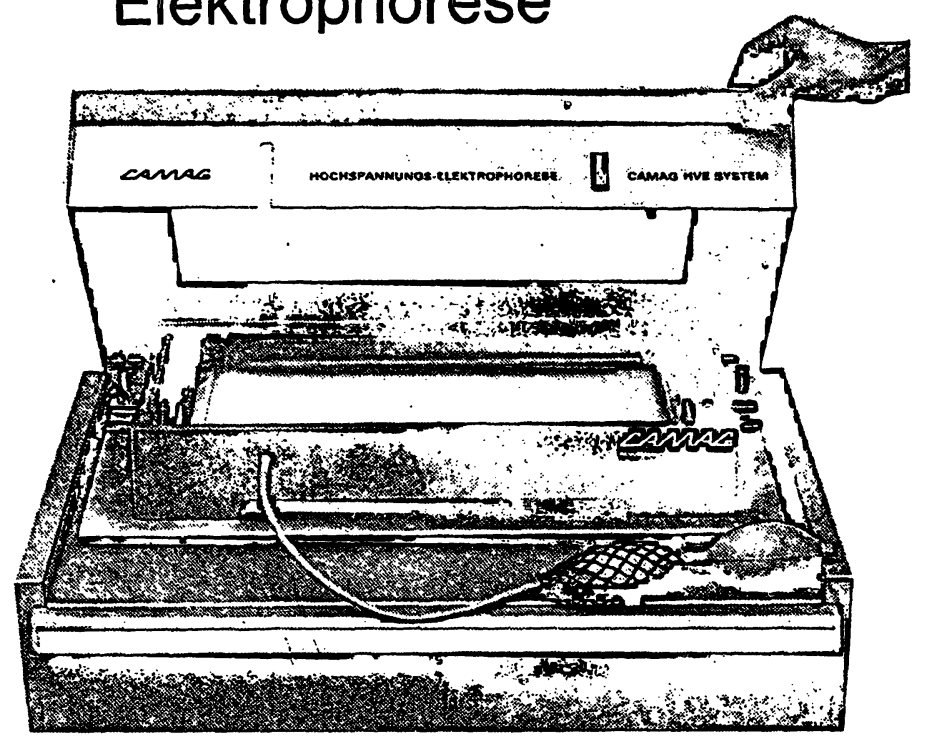

Mit dem dauert z. B. eine Aminosäure-Trennung knapp 15 Minuten

Weitere Beispiele: Oligopeptide

Kohlenhydráte

Porphyrine

Phenole

Vitamine

Das CAMAG-System ist besonders wirtschaftlich, sicher und unkompliziert.

Verlangen Sie unseren Prospekt - oder noch besser eine

Demonstration in Ihrem Labor

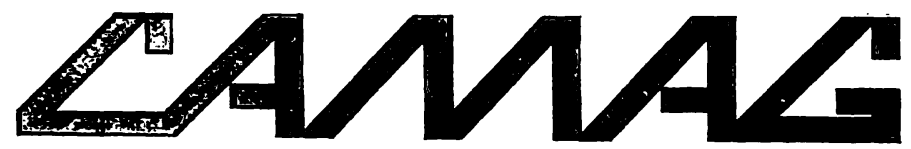

Chemie-Erzeugnisse und Adsorptionstechnik AG
4132 Muttens/Schweiz Homburgerstrasse 24 Telefon (061) 531430
1000 Berlin 41

Bismarckstrasse 27-29

Telefon (0311) 7915091
Ärger mit den

Schläuchens

Wir bei Heidolph: wissen darum und bieten thenen deshabrice punfoespovan.

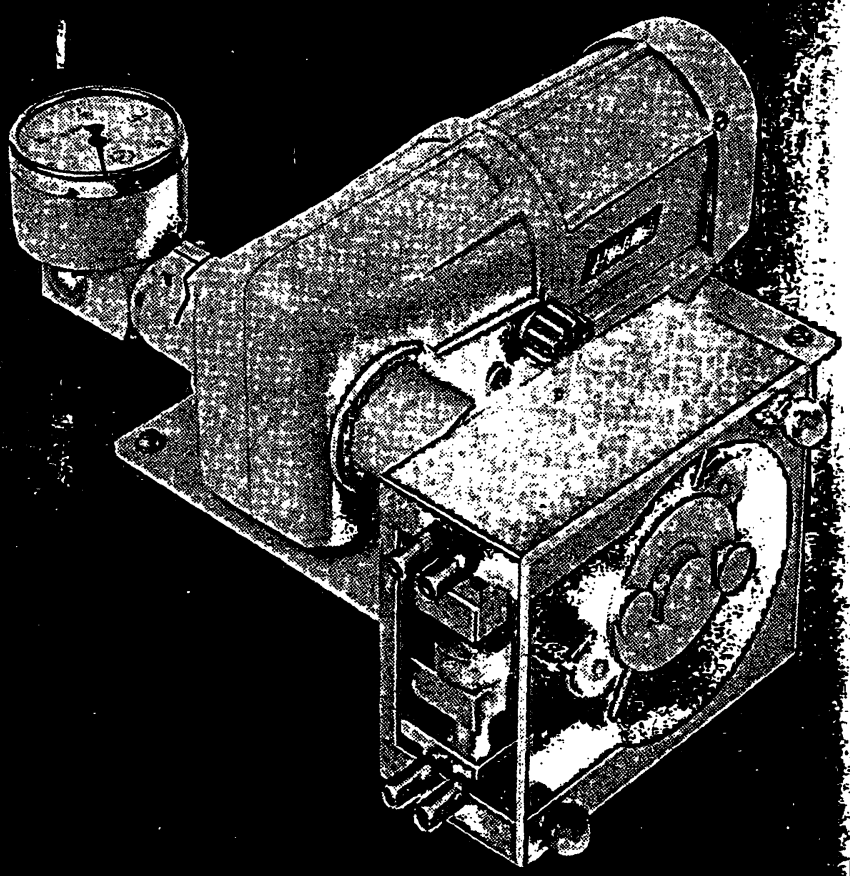

Nicht mehr starr der Abstand zwischen Anpreßflächen und Rollen, sondern anpassungsfähiğan Schläuche mit Wandstärken zwischen 0,5 und 2,5 $\mathrm{mm}$ und lichten Weiten zwischen 2 und $8 \mathrm{~mm}$. Und das ohne Werkzeug!

Stufenlos regelbar die Drehzahl. Abzulesen auf dem angebauten Drehzahlmesser.

Damit Sie dies alles als wesentliche Vorteile beurteilen können, senden wir Ihnen auf Anforderung gerne ausführliches Informationsmaterial.

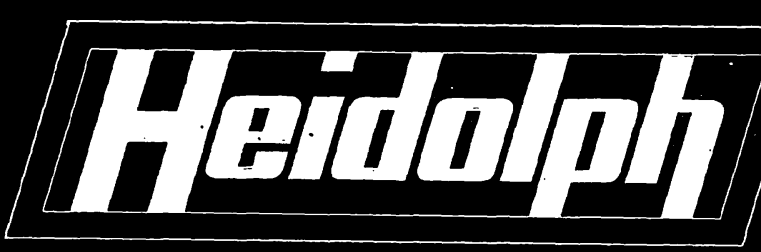

Heidolph-Elektro KG · D 8420 Kelheim/Germany Telefon (0 94 41) 7533 . Telex 065415d 


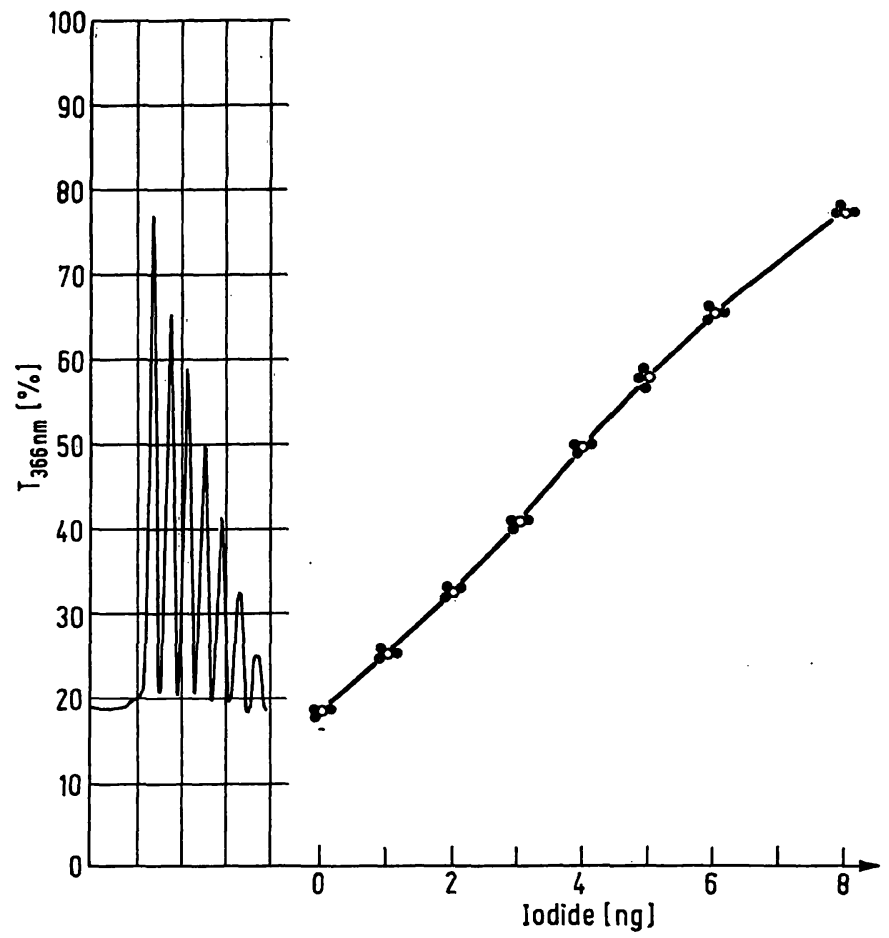

Fig. 3

Standard curve of the microchemical iodine determination

On the left is shown the automatic recording of the standards. Open circles $(O)$ are means of triplicate determinations (8)

\section{Results}

\section{The different steps of the method}

On the first column the $T_{3}$ and $T_{4}$ content of serum was completely retained, as demonstrated by experiments with radioactive $T_{3}$ and $T_{4}$. From this first column $94 \%$ of radioactive $T_{3}$ and $T_{4}$ could be concomitantly eluted in a volume of $8 \mathrm{ml}$ using continuous chromatography. Since the eluate of the first column was simultaneously layered onto the second column, no intermediate concentration step was necessary. Continuation of the chromatography in this closed system with the same buffer separated $T_{3}$ from $T_{4}$. After the elution from the second column, the radioactive $T_{3}$ could be completely recovered in approximately $45 \mathrm{ml}$ (Fig. 2). Complete recovery of the $\mathrm{T}_{4}$ was obtained in approximately $60 \mathrm{ml}$, separated from the $T_{3}$ peak by an interval of $20 \mathrm{ml}$ free of radioactivity (Fig. 2).

Prior to quantitation, the eluates containing $T_{3}$ or $T_{4}$ had to be reduced in volume. Continuous acidification of the eluates from the Sephadex columns (Fig. -1, d) in the closed system used, was necessary for complete retention of $T_{3}$ and $T_{4}$ respectively on two separate cation exchange resin columns. For the final elution of $T_{3}$ or $T_{4}$ from the Bio-Rex columns a yield of $95 \%$ of the radioactivity in $5 \mathrm{ml}$ of $5 \mathrm{~N} \mathrm{NH}_{3}$ was obtained.

The sensitivity of the microchemical iodine determination (13) permitted the measurement of $0.5 \mathrm{ng}$. iodine from thyroid hormones (Fig. 3) after subtraction of the blank. The introduction of the reductive dehalogenation step made it possible to estimate the iodine content of the thyroid hormones by a standard curve of iodide. The yield was $96 \%$ for cold hormones (13).

The blank value for the whole procedure was about $1 \mathrm{ng}$ iodine, mainly due to the concentrating step on the Bio-Rex column. Recently, we therefore used Sephadex LH-20 instead of Bio-Rex 70. From $1 \mathrm{ml}$ Sephadex LH-20 columns $T_{3}$ or $T_{4}$ were completely eluted in $3 \mathrm{ml}$ solution of $15 \mathrm{~N} \mathrm{NH}_{3}: 50 \%(\mathrm{v} / \mathrm{v})$ aqueous methanol $=1: 1$, resulting in blank values of less than $0.5 \mathrm{ng}$.

\section{Quality control}

The quality control of the complete procedure (Fig. 1) for the separate determination of $T_{3}$ and $T_{4}$ is presented in Table 1. The recovery of added radioactive thyroid hormones was checked from day to day and was $87 \%$ for $T_{3}$ and $88 \%$ for $T_{4}$. The recovery of cold $T_{3}$ was studied by the following experiment. Three nanograms $\mathrm{T}_{3}$ were added to $2.0 \mathrm{ml}$ control serum, the latter containing $3.26 \pm 0.21 \mathrm{ng} \mathrm{T}_{3} \quad(\mathrm{~N}=6)$. After the whole procedure $5.90 \pm 0.33 \mathrm{ng} \mathrm{T}_{3} \quad(\mathrm{~N}=4)$ were recovered, which is equal to $88 \%$ of the originally added $\mathrm{T}_{3}$.

The precision of the method was determined from day to day with a control serum. The coefficient of variation was less than $10 \%$ for $\mathrm{T}_{3}$ and $7 \%$ for $\mathrm{T}_{4}$ (Table 1 ). The precision within a single assay was even better, namely $6.5 \%$ for $T_{3}$ and $2.7 \%$ for $T_{4}$ (12).

\section{Specifity}

The following rechromatography experiment was performed to check the overspill of $T_{4}$ into the $T_{3}$ peak (Table 2, Fig. 2):

Radioactive standards of $T_{3}$ and $T_{4}$ were incubated each with $2 \mathrm{ml}$ control serum and, after the whole separation procedure (Fig. 1, a-d), the peaks of the $T_{3}$ and $T_{4}$ area were concentrated on AG $50 \mathrm{~W}-\mathrm{X} 4$ instead of Bio-Rex 70 as the third columns. These columns were used as the first columns of the rechromatography through the whole procedure (Fig. 1, a-d). The results are shown in Table 2 . The radio-

Table 2

Rechromatography of radioactive $T_{3}$ and $T_{4}$ standards For technical details and explanation see text

\begin{tabular}{|c|c|c|c|}
\hline & $\mathrm{I}^{-}$ & $\mathrm{T}_{3}$ & $\mathrm{~T}_{4}$ \\
\hline 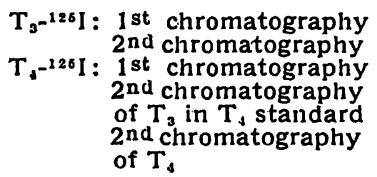 & $\begin{array}{l}2.1 \% \\
1.6 \% \\
-\end{array}$ & $\begin{array}{l}91.7 \% \\
\downarrow \\
1.31 \% \\
0.09 \%\end{array}$ & 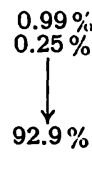 \\
\hline
\end{tabular}

active standards used were contaminated with $2.1 \%$ iodide $\left(\mathrm{T}_{3}\right)$ and $1.6 \%\left(\mathrm{~T}_{4}\right)$ respectively. The overall yield was $91.7 \%$ for $T_{3}$ and $92.9 \%$ for $T_{4}$ after rechromatography. The radioactive contamination of the $T_{3}$ standard found in the ' $T_{4}$ area was $0.99 \%$ after the first chromatography, $0.25 \%$ after the second chromatography. These radioactivities were probably due 
to tailing of the $T_{3}$ peak and not due to real $T_{4}$ contamination.

The $\mathrm{T}_{4}$ standard was contaminated with $1.31 \%$ of radioactivity which was identified as $\mathrm{T}_{3}$ in the second chromatography (Table 2). Rechromatography of the $\mathrm{T}_{4}$ peak showed only a very small amount of $\mathrm{T}_{3}(0.09 \%)$. Thus, the overspill of $T_{4}$ into $T_{3}$ was less than $0.1 \%$ of total $\mathrm{T}_{4}$. - Further, $350 \mathrm{ng} \mathrm{T}_{4}$ of a freshly prepared cold standard solution were applied to the procedure without prior chromatographic purification. No measurable $T_{3}$ was found.

The iodide content of serum is eluted from the first column (Fig. 1) and discarded together with the serum proteins. - The MIT and DIT fractions which are eluted from the first column onto the second column appear before the $T_{3}$ peak, as proved with radioactive standards.

Added inactive tetraiodothyroacetic acid (tetrac) was eluted together with $\mathrm{T}_{4}$. - When a serum heavily contaminated with exogenous iodine (e.g. X-ray contrast media), as shown by excessively high $\mathrm{PB}^{127} \mathrm{I}$ values, was subjected to the procedure, some overspill of the contaminant into the $\mathrm{T}_{3}$ area was observed.

\section{Eutbyroid controls and nontoxic goiter patients}

The normal ranges of the total serum $T_{3}$ and $T_{4}$ contents calculated from the 23 euthyroid controls studied so far are given in Table 1. The $\mathrm{T}_{3}: \mathrm{T}_{4}$ ratio in serum was $1: 44$ on a molar basis.

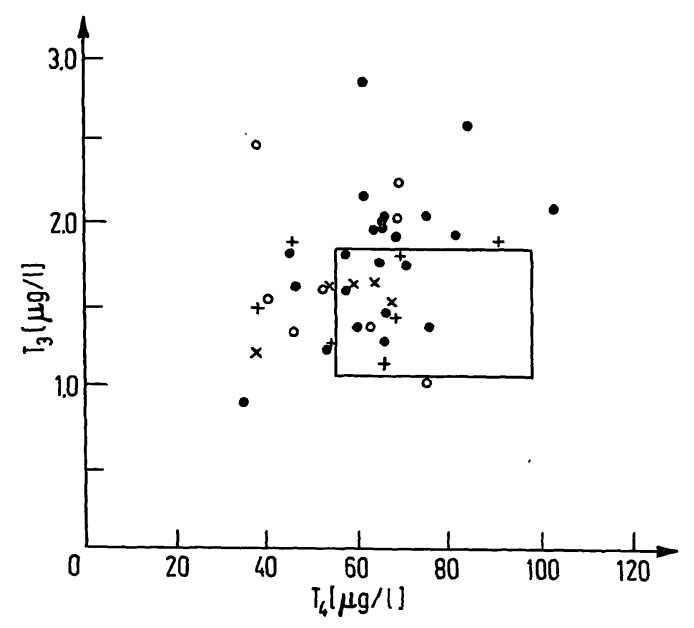

Fig. 4

Individual serum $T_{3}$ levels versus $T_{4}$ levels of patients with nontoxic goiter in comparison with the normal range of euthyroid controls The rectangle represents the normal range (means $\pm 2 S D$ ) of $T_{3}$ and $T_{4}$ of euthyroid controls. Diffuse nontoxic goiter $(\theta, N=24)$, nodular nontoxic goiter $(t, N=7)$, recurrent diffuse nontoxic goiter $(O$, $N=7)$ and recurrent nodular nontoxic goiter $(x, N=5)$

Figure 4 shows the normal tanges of $\mathrm{T}_{3}$ and $\mathrm{T}_{4}$ of euthyroid controls and the individual $\mathrm{T}_{3}$ and $\mathrm{T}_{4}$ levels of patients with diffuse or nodular nontoxic goiter. The individual values of $T_{4}$ of the goiter patients are in the lower half of the normal range or just below. In contrast, the $T_{3}$ levels are normal or slightly elevated. The same was found for recurrent nontoxic goiter. The means of the serum levels of patients $(N=43)$ with nontoxic goiter were significantly elevated for $\mathrm{T}_{3}$ : $1.71 \pm 0.41$ (S. D.) $\mu \mathrm{g} / 1$ compared with euthyroid controls $(1.46 \pm 0.20 \mu \mathrm{g} / \mathrm{l}, \mathrm{N}=23, \mathrm{p}<0.005)$. The $\mathrm{T}_{4}$ values were significantly diminished: $61.9 \pm 14.2 \mu \mathrm{g} / 1$ versus $76.5 \pm 10.7 \mu \mathrm{g} / 1(\mathrm{p}<0.0005)$. The $\mathrm{T}_{3}: \mathrm{T}_{4}$ ratio (ng: $\mu \mathrm{g}$ ) of nontoxic goiter patients was therefore significantly higher than of euthyroid controls: 28.8 \pm 8.9 versus $19.6 \pm 4.1(p<0.0005)$.

\section{Discussion}

The normal range of the total $\mathrm{T}_{3}$-level in serum $(1.06-1.86 \mu \mathrm{g} / \mathrm{l})$ obtained by this method is obviously lower than the normal ranges reported by other authors $(1-4,7)$. This discrepancy is probably caused by the use of different methods. The two main sources for excessively high $T_{3}$ levels are: (1) $T_{4}$ overspill into $T_{3}$ and (2) artefacts arising from chromatography. Paper chromatographic techniques have recently been seriously questioned in this respect (4-7).

The method presented here has the following advantages:

1. Column chromatography is used throughout the method without intermediary organic solvent extraction or volume reduction steps before the separation of $\mathrm{T}_{3}$ from $\mathrm{T}_{4}$. This diminishes the chance of chromatographic artefacts, for example ester formation $(4,5,7)$. In addition this approach permitted simultaneous chromatography of 25 samples.

2. The automation of the chromatography on three consecutive columns (closed system) and of the iodine determination (13) obviously resulted in sufficient standardization of the yields (average $87 \%$ ). As a consequence the addition of internal radioactive standards to all samples could be omitted. Internal radioactive standards are probably sources for overcorrection (6). This might be of major importance in methods with yields of around $50 \%$, especially when the radioactive standards were contaminated or had low specific activities.

3. The chromatographic system used separates $T_{3}$ from $\mathrm{T}_{4}$ on the basis of different $\mathrm{pK}$ values of the phenolic groups of the molecules ( 6.73 for $T_{4}$ and 8.45 for $T_{3}$ ) (14). $T_{3}$ is eluted before $T_{4}$ with an overspill of less than $0.1 \%$ of total $\mathrm{T}_{4}$ into $\mathrm{T}_{3}$. Therefore the error in the $\mathrm{T}_{3}$ determination due to $\mathrm{T}_{4}$ contamination is. less than $5 \%$.

Our results for $T_{3}$ levels are in good agreement with the recently published data based on radioimmunological determination (15).

The serum $\mathrm{T}_{4}$ levels of patients with nontoxic goiter tend to be low-normal, the serum $T_{3}$ levels to be normal or slightly elevated. The patients are from an area of iodine deficiency with urinary iodine excretions of approximately $40 \mu \mathrm{g} /$ day (unpublished data). Nontoxic goiter patients of our area were earlier shown to have slightly diminished values of $\mathrm{PBI}$ and $\mathrm{T}_{3}$ - uptake as compared with euthyroid controls $(16,17)$. The same 
was observed for the group of patients studied here. The normal or even elevated total $T_{3}$ levels could be interpreted as an attempt to preserve euthyroidism in the patients with endemic goiter. Determination of $\mathrm{TSH}$ levels in our patients will show, if the increment of $T_{3}$ in relation to $T_{4}$ is a consequence of elevated TSH levels, as postulated by some authors $(17,18)$ and questioned by others $(19,20) \cdot T_{3}$ preference could also be interpreted on the basis of substrate deficiency (iodide) for thyroid hormonogenesis (21).

\section{References}

1. Naumann, J. A., A. Naumann and S. C. Werner, J. clin. Invest. 46, 1346 (1967). - 2. Sterling, K., D. Bellabarba, E. S. NeWMAN and M. A. BrenNeR, J. clin. Invest. 48, 1150 (1969). 3. Stering, K., Recent Progr. Horm. Res. 26, 249 (1970). 4. Bellabarba, D. and K. Sterling, J. clin. Endocr., Springfield 29, 1510 (1969). - 5. Radichevich, I. and S. C. Werner, J. clin. Endocr., Springfield 32, 350 (1971). - 6. Frsher, D. A. and J. H. Dussault, J. clin. Endocr., Springfield 32, 675 (1971). 7. WAkNER, H. W. and C. A. Gorman, N. Engl. J. Med. 284, 225 (1971). - 8. BRown, B. L., R. P. EkINS, S. M. ElLIs and W. S. Reith, Nature 226, 359 (1970). - 9. Chopra, I. J., J. C. Nelson, D. H. Solomon and G. N. Beall, J. clin. Endocr., Springfield 32, 299 (1971). - 10. GHARIB, H., W. E. MAYBERRY and R. J. RYAN, J. clin. Endocr., Springfield 31, 709 (1971). - 11. HorN, K., G. Hallhuber, T. Ruhi and P. C. Scriba, Acta endocr. (Kbh.) Suppl. 152, 85 (1971). - 12. RuhL, T., J. HabermanN, K. Horn and P. C. Scriba, Acta endocr. (Kbh.) Suppl. 155, 8 (1971). -
13. Horn, K., R. Landgraf, T. Ruhl und P. C. Scriba, Z. analyt. Chem. 252, 267 (1969). - 14. Robbins, J. and J. E. Rall, The iodine-containing hormones. In: Hormones in blood, GRAY, C. H. and A. L. Bacharach, Edits, 2nd edition, Acad. Press, London and New York, (1967), 383. - 15. Mitsuma, T., N. Nirei, J. Colucci, C. Thaw, H. Nadel, M. C. Gershengorn and C. S. Hollander, Abstract, 53. Meet. Endocr. Soc., San Francisco, 1971. - 16. Heinze, H. G., J. Beckebans, K. W. Frey, H. W. Pabst, J. Richter, K. Schwarz und P. C. Scriba, Fortschr. Röntgenstr. 110, 717 (1969). - 17. SCRIBA, P. C. und K. HORN, Med. Klin. 64, 1737 (1969). - 18. Coble, Y. D. and P. O. Kohler, J. clin. Endocr., Springfield 31, 220 (1970). - 19. WAHNER, H. W., W. E. Mayberry, E. Gaitan and J. E. Gaitan, J. clin. Endocr., Springfield 32, 491 (1971). - 20. Hall, R., J. Amos and B. J. Ormston, Brit. med. J. 1971/I, 582. - 21. Studer, H. und M. A. Greer, Die Regulation der Schilddrüsenfunktion bei Jodmangel. Huber, Bern und Stuttgart (1966).

Dr. med. Klaus Horn cand. med. 'Thomas Ruhl PD Dr. med. Peter C. Scriba

II. Medizinische Klinik der Universität München 8 München 15

Ziemssenstraße 1 